\title{
BRUCELLOSIS IN PREGNANCY: CASE REPORTS WITH DIFFERENT OUTCOMES IN AN ENDEMIC REGION
}

\author{
Mile Bosilkovski ${ }^{1}$, Marjan Stojovski ${ }^{1,2}$, Dijana Siskova $^{3}$, Aleksandar Ridov $^{4}$, \\ Emilija Kostoska ${ }^{5}$ and Kiril Krstevski ${ }^{6}$
}

${ }^{1}$ Medical Faculty, Ss Cyril and Methodius University, Skopje, Republic of Macedonia;

${ }^{2}$ University Hospital of Obstetrics and Gynecology, Skopje, Republic of Macedonia;

${ }^{3}$ Department of Infectious Diseases, Shtip Medical Center, Shtip, Republic of Macedonia;

${ }^{4}$ Department of Infectious Diseases, Kavadarci Medical Center, Kavadarci, Republic of Macedonia;

${ }^{5}$ Department of Infectious Diseases, Prilep Medical Center, Prilep, Republic of Macedonia;

${ }^{6}$ Faculty of Veterinary Medicine, Ss Cyril and Methodius University, Skopje, Republic of Macedonia

SUMMARY - Different outcomes of brucellosis in pregnancy regarding the fetus/neonate and the mother are described. Medical records of five pregnant women with brucellosis were retrospectively analyzed. Patients were treated in several departments of infectious diseases in the Republic of Macedonia between 1995 and 2009. The diagnosis of brucellosis was based on clinical findings compatible with the disease supported by detection of specific antibodies. Pregnancy outcomes in patients were as follows: spontaneous abortion, intrauterine fetal death, premature delivery in two cases (one with twin pregnancy) and term delivery. One of the women experienced relapse. Follow-up results of neonates showed no infection and their normal growth and development. Brucellosis, especially if acquired in early pregnancy, can have an impact on pregnancy outcome. In endemic regions, in pregnant women with persisting fever and unspecific manifestations one should always have in mind brucellosis. In these areas, cases with unexplained spontaneous abortion, intrauterine fetal death and premature delivery should also be investigated for brucellosis.

Key words: Abortion; Brucellosis; Intrauterine fetal deatb; Pregnancy; Preterm labor; Term labor

\section{Introduction}

Brucellosis is a zoonosis, which is mainly acquired through contact with infected animals or their products, or by consumption of improperly cooked food of animal origin ${ }^{1}$. In line with this notion, brucellosis is most commonly an endemic or professionally acquired disease. It affects all age groups of both genders, including pregnant women. Brucellosis is rare in pregnancy ${ }^{2}$, with an incidence in endemic areas from $1.3 \%$ to $12.2 \% \%^{3-5}$. In other words, in these regions,

Correspondence to: Mile Bosilkovski, $M D, P h D$, ul. Božidar Adžija br. 18/1-6, 1000 Skopje, R. Macedonia

E-mail:milebos@yahoo.com

Received September 22, 2016, accepted June 26, 2017
$1.5 \%$ to $17 \%$ of cases with brucellosis are pregnant women ${ }^{4,6-8}$.

Unlike animal brucellosis, which is mainly characterized by affecting the genital system and consequently resulting in abortions and sterility ${ }^{1,9}$, there is controversy regarding the relationship between human brucellosis and pregnancy outcome ${ }^{10}$. Some authors think that pregnant women with brucellosis do not have a larger number of abortions than do those with other bacteremic infections ${ }^{11-13}$. These attitudes are based on the fact that, unlike animal placenta, human placenta has no, or has low amounts of erythrol, as well as the presence of anti-brucellar activity in human amniotic fluid ${ }^{3,5,8,14}$. On the other hand, there are reports that brucellosis in pregnant women, especially when 
Brucella melitensis is the causative agent, may lead to an increased rate of spontaneous abortion, intrauterine fetal death (IUFD), and premature delivery. The main reasons for adverse obstetric outcome may be attributed to maternal bacteremia, endotoxemia, acute febrile reaction, disseminated intravascular coagulation, placentitis $^{4,5,7,8,15-17}$, or even allergic mechanism in chronic brucellosis 7 . The possible complications in brucellosis during pregnancy should also be considered, e.g., low birth weight ${ }^{2,18}$, neonatal infection ${ }^{5,19-22}$, maternal and neonatal death ${ }^{18}$, and even transmission of the disease from patients to medical personnel ${ }^{23,24}$. Brucellosis during pregnancy has not been shown to be associated with congenital anomalies ${ }^{2,24,25}$, although there are communications reporting contrary results ${ }^{18}$. Our aim was to present different outcomes of brucellosis in pregnancy.

\section{Methods}

We retrospectively analyzed medical records of five pregnant women with brucellosis that were treated in the departments of infectious diseases in the Republic of Macedonia between 1995 and 2009. The study was approved by the local institutional Review Boards in compliance with the principles of the Declaration of Helsinki and its later amendments. All patients gave their written consent for publishing their medical documentation by preserving their anonymity.

The diagnosis of brucellosis was based on clinical findings compatible with the disease supported by detection of specific antibodies, Rose Bengal and either standard tube agglutination test (STA) plus Brucella Coombs test or Brucellacapt test at significant titers, as previously described ${ }^{26,27}$.

None of the presented patients had a prior history of brucellosis, chronic venereal diseases, pathologic pregnancies or abortions. At admission, all patients underwent routine hematologic and biochemical tests including hemoglobin $(\mathrm{Hb})$, red blood cell (RBC) count, white blood cell (WBC) count, neutrophils $(\mathrm{Ne})$, platelet $(\mathrm{Pt})$ count, alanine aminotransferase/aspartate aminotransferase (ALT/AST), creatinine, erythrocyte sedimentation rate (ESR), C-reactive protein (CRP) and urine culture. Patients were managed by an interdisciplinary team including infectious disease and obstetric specialists. Their babies were man- aged by pediatricians neonatologists and infectious disease specialists.

\section{Results}

\section{Case 1}

A 25-year-old patient, teacher, mother of one healthy child. This was her second pregnancy in the $11^{\text {th }}$ gestational week. The patient had been ill for two weeks until the diagnosis of brucellosis was made; she had back pain, malaise, sweating, headache and temperature of $38.4{ }^{\circ} \mathrm{C}$. She acquired the disease through consumption of soft sheep cheese. At admission, wrist arthritis was recorded. Gynecologic examination was unremarkable. Laboratory analyses showed the following results: $\mathrm{Hb} 120 \mathrm{~g} / \mathrm{L}, \mathrm{RBC} 4100 \times 10^{12} / \mathrm{L}, \mathrm{WBC}$ 4.6x10\%/L, Ne 62\%, P1 200x1012/L, ALT/AST 22/18 $\mathrm{U} / \mathrm{L}$, creatinine $64 \mu \mathrm{mol} / \mathrm{L}, \mathrm{ESR} 60 \mathrm{~mm} / \mathrm{h}, \mathrm{CRP} 64$ $\mathrm{mg} / \mathrm{L}$, urine culture negative, Rose Bengal positive, STA 1/1280, Brucella Coombs test 1/1280.

Immediately after establishment of the diagnosis, treatment with rifampin plus cotrimoxazole was initiated. In the first week of treatment, subfebrile temperatures were recorded, with withdrawal of wrist arthritis on day 6 of treatment. Two weeks from the beginning of treatment, i.e. in the $13^{\text {th }}$ week of gestation, vaginal bleeding was recorded. Hexoprenaline and isoptin were used to treat the condition, however, three days later, the pregnancy ended with spontaneous abortion. Pathologic findings showed nonspecific inflammatory changes.

After the spontaneous abortion, doxycycline was added to the combination of rifampin and cotrimoxazole for the next 4 weeks. Three weeks after this treatment had been completed relapse was recorded and the patient was re-treated with the same regimen for 45 days. During 36 months of follow-up, the disease outcome was favorable.

\section{Case 2}

A 28-year-old patient, housewife, mother of three healthy children. When brucellosis was diagnosed, she was in the $10^{\text {th }}$ week of pregnancy. The patient was engaged in processing raw milk as part of a family business of sheep breeding. Several family members had previously suffered from brucellosis. Her illness began six weeks prior to admission, with temperature of 39 
${ }^{\circ} \mathrm{C}$, fever, malaise, arthralgias, sweating. Gynecologic examination at admission was otherwise unremarkable with the following laboratory results: $\mathrm{Hb} 136 \mathrm{~g} / \mathrm{L}$, RBC 4490x1012/L, WBC 4,0x10\%/L, Ne 58\%, P1 251x10 $12 / \mathrm{L}$, ALT/AST 28/22 U/L, creatinine 96 $\mu \mathrm{mol} / \mathrm{L}$, ESR $20 \mathrm{~mm} / \mathrm{h}, \mathrm{CRP} 24 \mathrm{mg} / \mathrm{L}$, urine culture negative, Rose Bengal positive, STA 1/320 Coombs $1 / 1280$.

The patient was treated with rifampin plus cotrimoxazole for 45 days. Defervescence was achieved on the second day of therapy introduction. During the treatment, the patient had regular gynecologic controls with normal findings. In the $28^{\text {th }}$ week of pregnancy (3 months after antibrucellar treatment had been finished) the mother noticed absence of fetal movements. Ultrasound revealed intrauterine fetal death and a dead baby weighing $2100 \mathrm{~g}$ was delivered by provoked contractions. Autopsy was not made. Microbiological examinations showed that some infectious agents (Toxoplasma, Rubella, Cytomegalovirus, Treponema, Chlamydia, Ureaplasma, Herpes simplex) were not the cause of IUFD. During one year follow-up period, no relapses were recorded.

\section{Case 3}

A housewife, at the age of 20 years, first pregnancy, 30 weeks of gestation. Brucellosis was acquired through direct contact with infected sheep and goats; other family members had brucellosis at the same time. The disease began two months prior to admission to the hospital, and predominant symptoms were malaise, pains in the right hip, temperature of $39^{\circ} \mathrm{C}$, night sweats, reduced appetite, and headache. Gynecologic examination at admission was normal and the findings of laboratory analyses were as follows: $\mathrm{Hb} 92$ $\mathrm{g} / \mathrm{L}, \mathrm{RBC} 3430 \times 10^{12} / \mathrm{L}, \mathrm{WBC} 14.0 \times 10^{9} / \mathrm{L}, \mathrm{Ne} 64 \%, \mathrm{Pl}$ $278 \times 10^{12} / \mathrm{L}, \mathrm{Ne} 52 \%$, ALT/AST 12/16 U/L, creatinine $75 \mu \mathrm{mol} / \mathrm{L}$, ESR $90 \mathrm{~mm} / \mathrm{h}, \mathrm{CRP} 84 \mathrm{mg} / \mathrm{L}$, urine culture negative, Rose Bengal positive, Brucellacapt $1 / 5120$.

Treatment with rifampin plus cotrimoxazole was initiated. Defervescence was achieved on the third day. Fourteen days after the treatment had been initiated ( $32^{\text {nd }}$ gestational week) the mother delivered spontaneously a baby boy weighing $2350 \mathrm{~g}$ with Apgar score $7 / 8$. Serologic testing of the baby showed negative Rose Bengal and Brucellacapt $1 / 80$. The baby was formula-fed, and his postnatal development was normal.
The treatment of the mother in the course of the next 4 weeks after delivery continued with rifampin plus cotrimoxazole plus doxycycline.

The mother was followed-up for 19 months; she had no problems; the baby was followed-up for 1 year; he had normal development without any symptoms/ signs and negative Brucellacapt at the end of the first year.

\section{Case 4}

A 27-year-old patient, administrative employee, her first twin pregnancy; brucellosis was diagnosed in her $20^{\text {th }}$ gestational week. The patient suffered from excessive sweating, malaise, headache, reduced appetite, arthralgias, nausea, and vomiting for 3 weeks. Her pregnancy was regularly controlled and it was without any problems. There were no data for contacts with infected animals or convincing indicators that the disease had been acquired by ingestion of suspicious food. At admission laboratory results were as follows: $\mathrm{Hb}$ $109 \mathrm{~g} / \mathrm{L}, \mathrm{RBC} 3450 \times 10^{12} / \mathrm{L}, \mathrm{WBC} 9.3 \times 10^{9} / \mathrm{L}, \mathrm{Ne}$ $80 \%$, P1 283×1012/L, ALT/AST 124/68 U/L, creatinine $84 \mu \mathrm{mol} / \mathrm{L}$, ESR $100 \mathrm{~mm} / \mathrm{h}$ CRP $46 \mathrm{mg} / \mathrm{L}$, Rose Bengal positive, Brucellacapt $1 / 2560$.

The patient was treated with rifampin plus cotrimoxazole for 45 days. She was regularly followed-up by infectious diseases and gynecology specialists. Cesarean section was performed at $32^{\text {nd }}$ week of pregnancy, six weeks after completion of the antibrucellar treatment. She had a preterm delivery due to cardiotocographic signs of fetal distress. The surgical procedure proceeded without complications. Birth weight of the newborn male twins was 1290 and $1770 \mathrm{~g}$, and Apgar score in both babies was 5/6/7. Initial Rose Bengal was positive in the babies, and Brucellacapt test was 1/160 and $1 / 80$. The babies were in the incubator in the first 3 weeks and were formula-fed.

Psychophysical development of the babies was normal during one year follow-up, and Rose Bengal and Brucellacapt were negative at nine months of delivery. The course of brucellosis in the mother was satisfactory, without relapses.

\section{Case 5}

A 29-year-old patient, housewife, mother of 3 healthy children. Brucellosis was diagnosed at $30^{\text {th }}$ week of gestation of her fourth pregnancy. She ac- 
quired the disease while processing milk and consuming young cheese. Her family was engaged in sheep breeding and several family members had been previously or were currently treated for brucellosis. The disease started three months prior to her admission, when she presented with temperature of $38.2^{\circ} \mathrm{C}$, sweating, malaise, headache, arthralgias and left hip arthritis. Gynecologic examination at admission was unremarkable, and laboratory analyses showed $\mathrm{Hb} 87 \mathrm{~g} / \mathrm{L}, \mathrm{RBC}$ 3250x1012/L, WBC 7.8x10\%/L, P1 263×10²/L, ALT/ AST 54/68 U/L, creatinine $56 \mu \mathrm{mol} / \mathrm{L}$, ESR $50 \mathrm{~mm} / \mathrm{h}$, CRP $2 \mathrm{mg} / \mathrm{L}$, urine culture negative, Rose Bengal positive, STA 1/320 Coombs 1/640.

The patient was treated with rifampin plus cotrimoxazole for 45 days. Defervescence was achieved on the fourth day after initiation of treatment, and peripheral arthritis withdrew 21 days later. Spontaneous vaginal delivery happened in the $39^{\text {th }}$ gestational week, three weeks after antibrucellar treatment had been completed. Birth weight of the male newborn was $3100 \mathrm{~g}$, and Apgar score was $9 / 9$. Initial serologic values in the newborn were positive Rose Bengal, STA 1/20 and Brucella Coombs test $1 / 40$. The baby was breastfed.

The baby presented with positive results of serologic tests in the first 6 months, after which they were negative. Throughout the follow-up period, the baby was in good general condition and with normal growth and development. The mother was followed-up for 6 months and no relapses were noticed.

\section{Discussion}

We have presented different outcomes in pregnancy as a result of human brucellosis. The reported incidence of spontaneous abortions, IUFD and preterm delivery during brucellosis ranges from $2.5 \%^{2}$ to $53 \%{ }^{4}$, $2 \%^{8}$ to $13 \% \%^{5}$ and $3 \%^{8}$ to $29 \%^{10}$. However, there are many studies that report term delivery as final outcome of pregnancy $y^{4,5,25,28,29}$.

Three of the patients presented (cases 2, 3 and 5) were exposed to direct contact with infected animals or their products as a source of acquiring the disease and at the same time brucellosis was found in several family members. These data have been presented in other studies, too ${ }^{7,30}$. A family history of brucellosis has been identified as a trait of brucellosis in endemic areas and reflects dietary habits and involvement in stockbreeding $^{31}$. It is also interesting that in two of our pa- tients (cases 1 and 5), peripheral arthritis was manifested, and it is the most frequent focal form of brucellosis in this endemic region ${ }^{31,32}$. Clinical presentation of brucellosis in our patients comprised manifestations that are unspecific and sometimes assigned to pregnancy itself, which might be a cause for delayed establishment of the diagnosis. Nevertheless, elevated temperature in pregnant women from endemic regions (which was found in four of our patients), has to arouse suspicion of brucellosis.

In cases 1 and 2, the disease was acquired early in pregnancy, which might be one of the causes of adverse outcome. A higher rate of spontaneous abortion in the first trimester was also noted by other authors ${ }^{5,18}$, while another group of authors report that abortion usually occurs in the second trimester ${ }^{8,33}$. Fever and vaginal bleeding known as factors that influence fetal $\operatorname{loss}^{34}$ were present in our case 1 , and although the treatment was started early, the outcome was poor. The cases presented in this study did not confirm the general notions that timely initiated treatment has positive impact (case 1 ) or that delayed treatment has adverse outcome of pregnancy (case 5). This might be due to the fact that we present isolated cases and not series of patients.

In the literature, there is controversy regarding the association of abortion with the magnitude of serology. According to some authors, the magnitude of serology in pregnant women is not associated with spontaneous abortions $s^{4,8}$, whereas others found higher incidence of abortion in cases with higher serology ${ }^{5-7}$. Our patients with spontaneous abortion, IUFD and prematurity (cases 1, 2, 3 and 4) had high initial serologic titers, whereas the patient with favorable pregnancy outcome (case 5) showed only moderately initially high titer.

In contrast to case 3 , where preterm labor happened during the treatment, in case 4 preterm labor happened 6 weeks after treatment completion and hence it is unclear whether brucellosis had an impact on preterm delivery. To our knowledge, our case of brucellosis during twin pregnancy with good outcome is the second case published in the literature ${ }^{35}$. IUFD described in our patient (case 2) appeared 3 months after completion of antibrucellar treatment and good clinical course in the mother. In the absence of other infectious agents, IUFD might be due to intrauterine brucellosis that had emerged in the very early pregnancy period.

Positive low-value serologic titers found in the newborns (cases 3, 4 and 5) in the first months after 
delivery were due to transplacental transmission of maternal antibodies ${ }^{7,25,36}$, and became negative during the follow-up period.

Prompt treatment in pregnant women with brucellosis is paramount to decrease devastating outcomes ${ }^{8,18}$. It is known that the risk of abortions and preterm labor is increasing without appropriate therapy ${ }^{4,8,18}$. In all of our patients, the treatment concerning antimicrobial choice and duration was uniform, i.e. a combination of rifampin and cotrimoxazole for 45 days. A limited number of treatment options of brucellosis in pregnancy is presented in the literature, having in mind that tetracyclines, quinolones, and very often aminoglycosides are not recommended in this population. Beside monotherapy or combined therapy with rifampin ${ }^{10,34}$ and cotrimoxazole ${ }^{37}$, ceftriaxone plus rifampin have also been used ${ }^{2}$, as well as aminoglycoside for one week plus rifampin and cotrimoxazole for six weeks ${ }^{18}$. In all our cases, the outcome was good in all mothers, including patient 1 who suffered a relapse and underwent a repeat treatment course. It is interesting that in patient 3 , although sudden delivery happened during the treatment with cotrimoxazole, the neonate did not manifest kernicterus as a possible risk if this drug is administered in the last week before delivery.

In conclusion, brucellosis can influence pregnancy outcome in spite of appropriate treatment, especially if brucellosis is acquired in the early stages of pregnancy. Thus, in endemic regions, screening for brucellosis in pregnant women should be performed. Brucellosis should be in mind in pregnant women with febrile symptoms and persistence of unspecific manifestations. In endemic regions, cases with unexplained spontaneous abortion, IUFD and premature delivery should also be investigated for brucellosis. Finally, in these regions, education may help prevent brucellosis during pregnancy.

\section{References}

1. Bosilkovski M, Rodriguez-Morales AJ. Brucellosis and its particularities in children travelers. Recent Pat Antiinfect Drug Discov. 2014;9:164-72. doi: 10.2174/1574891x106661504081 62624.

2. Gulsun S, Aslan S, Satici O, Gul T. Brucellosis in pregnancy. Trop Doct. 2011;41:82-4. doi: 10.1258/td.2011.100386.

3. Al-Tawfiq JA, Memish ZA. Pregnancy associated brucellosis. Recent Pat Antiinfect Drug Discov. 2013;8:47-50. doi: 10.2174 /1574891x11308010009.
4. Roushan MR, Baiani M, Asnafi N, Saedi F. Outcomes of 19 pregnant women with brucellosis in Babol, northern Iran. Trans R Soc Trop Med Hyg. 2011;105:540-2. doi: 10.1016/j. trstmh.2011.06.003.

5. Elshamy M, Ahmed AI. The effects of maternal brucellosis on pregnancy outcome. J Infect Dev Ctries. 2008;2:230-4. doi: 10.3855/jidc. 268 .

6. Sharif A, Reyes Z, Thomassen P. Screening for brucellosis in pregnant women. J Trop Med Hyg. 1990;93:42-3.

7. Kurdoglu M, Adali E, Kurdoglu Z, Karahocagil MK, Kolusari A, Yildizhan R, et al. Brucellosis in pregnancy: a 6-year clinical analysis. Arch Gynecol Obstet. 2010;281:201-6. doi: 10.1007/ s00404-009-1106-0.

8. Khan MY, Mah MW, Memish ZA. Brucellosis in pregnant women. Clin Infect Dis. 2001;32:1172-7. doi: 10.1086/319758.

9. Kurdoglu M, Cetin O, Kurdoglu Z, Akdeniz H. The effect of brucellosis on women's health and reproduction. Int J Women's Health Reprod Sci. 2015;3:176-83. doi 10.15296/ijwhr.2015.38.

10. Hackmon R, Bar-David J, Bashiri A, Mazor M. Brucellosis in pregnancy. Harefuah. 1998;135:3-7, 88.

11. Young EJ. Human brucellosis. Rev Infect Dis. 1983;5:821-42. doi: 10.1093/clinids/5.5.821.

12. Young EJ. An overview on human brucellosis. Clin Infect Dis. 1995;21:283-9. doi: 10.1093/clinids/21.2.283.

13. Spink WW. The Nature of Brucellosis. Minneapolis: University of Minnesota Press; 1956, p. 145-90.

14. Malone FD, Athanassiou A, Nores LA, Dalton ME. Poor perinatal outcome associated with maternal Brucella abortus infection. Obstet Gynecol. 1997;90:674-6. doi: 10.1016/s00297844(97)00345-1.

15. Aydın B, Beken S, Akansel R, Dilli D, Okumus N, Zenciroglu $\mathrm{A}$, et al. Prematurity due to maternal brucella infection and review of the literature. Turk J Pediatr. 2013;5:33-7.

16. Fernihough TJ, Munoz WP, Mahadeyo I. The role of Brucella abortus in spontaneous abortion among the black population. $\mathrm{S}$ Afr Med J. 1985;68:379-80.

17. Oscherwitz SL. Brucellar bacteremia in pregnancy. Clin Infect Dis. 1995;21:714-5. doi: 10.1093/clinids/21.3.714.

18. Vilchez G, Espinoza M, D’Onadio G, Saona P, Gotuzzo E. Brucellosis in pregnancy: clinical aspects and obstetric outcomes. Int J Infect Dis. 2015;38:95-100. doi: 10.1016/j. ijid.2015.06.027.

19. Dogan DG, Aslan M, Menekse E, Yakinci C. Congenital brucellosis: case report. Ann Trop Paediatr. 2010;30:229-31. doi: 10.1179/146532810X12786388978724.

20. Lubani MM, Dudin KI, Sharda DC, Abu Sinna NM, Al-Shab T, Al-Refe'ai AA, et al. Neonatal brucellosis. Eur J Pediatr. 1988;147:520-2. doi: 10.1007/BF00441980.

21. Giannakopoulos I, Nikolakopoulou NM, Eliopoulou M, Ellina A, Kolonitsiou F, Papanastasiou DA. Presentation of childhood brucellosis in western Greece. Jpn J Infect Dis. 2006;59:160-3.

22. Mosayebi Z, Movahedian AH, Ghayomi A, Kazemi B. Congenital brucellosis in a preterm neonate. Indian Pediatr. 2005; 42:599-601. 
23. Poulou A, Markou F, Xipolitos I, Skandalakis PN. A rare case of Brucella melitensis infection in an obstetrician during the delivery of a transplacentally infected infant.J Infect. 2006;53:e3941. doi: 10.1016/j.jinf.2005.09.004.

24. Mesner O, Riesenberg K, Biliar N, Borstein E, Bouhnik L, Peled N, et al. The many faces of human-to-human transmission of brucellosis: congenital infection and outbreak of nosocomial disease related to an unrecognized clinical case. Clin Infect Dis. 2007;45:e135-40. doi: 10.1086/523726.

25. Karcaaltincaba D, Sencan I, Kandemir O, Guvendag-Guven ES, Yalvac S. Does brucellosis in human pregnancy increase abortion risk? Presentation of two cases and review of literature. J Obstet Gynaecol Res. 2010;36:418-23. doi: 10.1111/ j.1447-0756.2009.01156.x.

26. Bosilkovski M, Kamiloski V, Miskova S, Balalovski D, Kotevska V, Petrovski M. Testicular infection in brucellosis: report of 34 cases. J Microbiol Immunol Infect. 2016 Mar 10. pii: S1684-1182(16)30004-4. doi: 10.1016/j.jmii.2016.02.004.

27. Bosilkovski M, Krteva L, Caparoska S, Labacevski N, Petrovski M. Childhood brucellosis: review of 317 cases. Asian Pac J Trop Med. 2015;8:1027-32. doi: 10.1016/j.apjtm.2015.11.009.

28. Gotuzzo E, Carillo C. Brucella. In: Gorbach SL, Bartlett JG, Blacklow NR, editors. Infectious Diseases (Third Edition). Philadelphia: Lippincott Williams \&Wilkins; 2004, p. 1837-45.

29. Cacace ML, Claros EA, Erazu KA, Escobar GI, Lucero NE. Congenital brucellosis in an infant. Vector Borne Zoonotic Dis. 2013;13:513-5. doi: 10.1089/vbz.2012.1165.

30. Sofian M, Aghakahani A, Velayati AA, Banifazl M, Eslamifar A, Ramezani A. Risk factors for human brucellosis in Iran: a case control study. Int J Infect Dis. 2008;12:157-61. doi: 10.1016/j.ijid.2007.04.019.

31. Bosilkovski M, Kirova-Urosevic V, Cekovska Z, Labacevski N, Cvetanovska M, Rangelov G, et al. Osteoarticular involvement in childhood brucellosis: experience with 133 cases in an endemic region. Pediatr Infect Dis J. 2013;32:815-9. doi: 10.1097/ INF.0b013e31828e9d15.

32. Bosilkovski M, Zezoski M, Siskova D, Miskova S, Kotevska V, Labacevski N. Clinical characteristics of human brucellosis in patients with various monoarticular involvements. Clin Rheumatol. 2016; 35:2579-84. doi 10.1007/s10067-016-3207-z.

33. Sarram M, Feiz J, Foruzandeh M, Gazanfarpour P. Intrauterine fetal infection with Brucella melitensis as a possible cause of second-trimester abortion. Am J Obstet Gynecol. 1974;119: 657-60. doi: 10.1016/0002-9378(74)90128-8.

34. Naji W, Naser W, Habahbeh M, Al-Dabbas M, Ma'aita M, Otaish I. Fetal loss in pregnancy complicated by brucellosis. Promise. 2011. Available at http://www.hpcpromise.org.jo/ node78/. Accessed Feb 10, 2013.

35. Ozbay K, Inanmis RA. Successful treatment of brucellosis in a twin pregnancy. Clin Exp Obstet Gynecol. 2006;33:61-2.

36. Kelly RT, Bibbins B. Pregnancy and brucellosis. Tex Med. 1987;83:39-41.

37. Skalsky K, Yahav D, Bishara J, Pitlik S, Leibovici L, Paul M. Treatment of human brucellosis: systematic review and metaanalysis of randomized controlled trials. BMJ. 2008;336:701-4. doi: 10.1136/bmj.39497.500903.25.

Sažetak

\section{BRUCELOZA U TRUDNOĆI: PRIKAZI SLUČAJA S RAZLIČITIM ISHODIMA U ENDEMSKOM PODRUČJU}

\section{Bosilkovski, M. Stojorski, D. Siskova, A. Ridov, E. Kostoska i K. Krsterski}

Opisuju se različiti ishodi bruceloze u trudnoći u odnosu na fetus/novorođenče i majku. Retrospektivno su analizirani medicinski zapisi za pet trudnica s brucelozom. Bolesnice su liječene u nekoliko klinika za zarazne bolesti u Republici Makedoniji u razdoblju od 1995. do 2009. godine. Dijagnoza bruceloze temeljena je na kliničkim nalazima sukladnima s bolešću i potkrijepljena otkrivanjem specifičnih protutijela. Ishodi trudnoće u ovih bolesnica bili su sljedeći: spontani pobačaj, intrauterina smrt fetusa, prijevremeni porođaj u dva slučaja (jedan s blizanačkom trudnoćom) i terminski porođaj. Recidiv je nastupio kod jedne od ovih žena. Rezultati praćenja novorođenčadi pokazali su odsutnost infekcije te normalan rast i razvoj. Bruceloza, osobito ako je stečena u ranoj trudnoći, može utjecati na ishod trudnoće. U endemskim područjima brucelozu treba uvijek imati na umu kod trudnica s ustrajnom groznicom i nespecifičnim manifestacijama. U ovim područjima testiranje na brucelozu treba provoditi i u slučaju neobjašnjenog spontanog pobačaja, intrauterine smrti fetusa i prijevremenog porođaja.

Ključne riječi: Pobačaj; Bruceloza; Intrauterina smrt fetusa; Trudnoća; Prijevremeni porođaj; Terminski porođaj 